ADDIN, Volume 11, Number 2, August 2017

\title{
DA'WAH AMONGST SECULAR COMMUNITIES: \\ Case Study on Al-Falah Mosque Indonesian Society, Berlin
}

\author{
M. Yunan Yusuf \\ UIN Syarif Hidayatullah Jakarta, Indonesia \\ yunan.yusuf@uinjkt.ac.id
}

\begin{abstract}
As the capital city of the Federal Republic of Germany, Berlin shows shades of very thick secular life. Society perceives that religious or supernatural beliefs are not considered as key understanding the world. Therefore, religion must be separated from issues of government and public affairs. It simply seen as merely an individual problem. Inevitably the nuances of life, it will affect Indonesian who are followers of Islam in Berlin. They will be a challenge, especially the Moslem communities who interact with fellow Moslems in maintaining Islamic values is very rarely. In addition, it also felt the rise of individualism attitude that emphasizes life nafsi-nafsi among themselves. This obviously affects the religious belief that a bit much degraded in consciousness and its practice. To overcome this, Al-Falah Mosque Indonesisches Weisheititsund Kulturzentrum (IWKZ) Berlin proselytizes enlightening discussion. These da'wah activities carried out can stem the infuence of secular life faced by Indonesian who are Moslem in Berlin.
\end{abstract}

Keywords: Berlin, Secular, Al-Falah Mosque, Da'wah. 
Abstrak

DA'WAH DI KALANGAN KOMUNITAS SEKULER: STUDI KASUS PADA MASYARAKAT INDONESIA DI MASJID AL-FALAH, BERLIN. Sebagai ibukota Republik Federal Jerman, Berlin menunjuk.kan nuansa kehidupan sekuler yang sangat tebal. Masyarakat merasa bahwa kepercayaan agama atau supranatural tidak dianggap sebagai pemahaman utama dunia. Karena itu, agama harus dipisabkan dari isu urusan pemerintahan dan publik. Ini hanya dilibat sebagai masalah individual semata. Nuansa kehidupan yang tidak dapat dibindari, hal itu akan mempengarubi orang Indonesia yang beragama Islam di Berlin. Hal ini menjadi tantangan, terutama sangat jarang masyarakat Moslem yang berinteraksi dengan sesama umat Islam dalam menjaga nilai-nilai Islam. Selain itu, dirasakan juga munculnya sikap individualisme yang menekankan kehidupan nafsi-nafsi diantara mereka sendiri. Hal ini jelas mempengarubi kepercayaan religius yang sedikit terdegradasi dalam kesadaran dan prakteknya. Untuk mengatasinya, Masjid Al-Falah Indonesisches Weisheitits-und Kulturzentrum (IWKZ) Berlin mendakwabkan diskusi yang mencerabkan. Kegiatan dakwab yang dilakukan bisa membendung pengarub kehidupan sekuler yang dihadapi orang Indonesia yang beragama Islam di Berlin.

Kata Kunci: Berlin, Sekuler, Masjid Al-Falah, Dakwah.

\section{A. Introduction}

Berlin, one of the cities in Germany, is selected by migrants from Indonesia as a residence. As a friendly country of Indonesia, Germany opens great opportunities for the Indonesian to live with various professions that are carried. Germany and Indonesia have a very different culture. Indonesia is known as a country that believes in God and Islam is population majority where the State participates in the religious care of its citizens. While Germany is a country known in much of the literature as a secular state, which assigns religious affairs to the citizens of their societies. 
Characteristically, as a secular country, Germany implements a secular policy in its government. This has a major impact on people's lives. Secularism is derived from the Latin word saeculum, which means space and time. The space refers to the notion of the world, while time points to the present or contemporary sense. Hence, saeculum means this world, and at the same time, the present, or the times. ${ }^{1}$

The above understanding has led to the view that between world and afterlife must be separated sharply. This puts a person on religious affairs not to be carried around in worldly affairs. The result is that religious matters may only be present in places of mere worship or church. The Berlin community shows a very thick secular life. Here, religious or supernatural beliefs are not regarded as an important key in understanding the world, and are therefore separated from the problems of government in decision-making. ${ }^{2}$

It is undeniable that such nuances of life will have an impact on the diverse Moslem Indonesian residing in Berlin. The authors' observations made in two previous Berlin visits i.e. 2014 and 2015, shows that the phenomenon of maintaining Islam in secular society is a serious issue. Imagine, very free social environment, permissive society attitude, and very high level of individual life, have given its influence to Moslem Indonesian.

This situation that leads people to view religion as a personal matter of each should not be interfered by others. Religion is only limited to the rituals that exist in places of worship cannot be brought to the public

${ }^{1}$ See Budhy Munawar-Rachman, Reorientasi Pembaharuan Islam Sekularisme, Liberalisme Paradigma Baru Islam Indonesia (Jakarta: Lembaga Studi Agama dan Filsafat, 2010), 169.

${ }^{2}$ https://id.wikipedia.org/wiki/Sekularisme\#Masyarakat_Sekuler, accessed on $15^{\text {th }}$ July 2016. 
space. With already certain amar makruf and nabi munkar in the framework of da'wah cannot run at all in this society system. If this continues to be left unchecked and it is not handled seriously, it is inevitable that there will be unintended consequences. That is the erosion of religious beliefs that will be experienced by Moslem Indonesian in Berlin. It may be that the erosion of trust is not instantly felt, but occurs slowly but surely.

The article focuses on revealing the efforts made by Moslem Indonesian community in Berlin, in this case, the AlFalah Mosque Indonesisches Weisheitits-und Kulturzentrum (IWKZ) Berlin in stemming of secular life influence.

\section{B. Discussion}

\section{Theoretical Framework}

The word da'wah comes from Arabic دعا-يدعو-دعوة which literally means call, appeal, or invitation. However, not all of them contain the meaning of da'wah. Only the call to goodness that means da'wah. That is to bring mad' $u$ (jama'ab/ communities invited) to change from a particular condition to better circumstances. The word is often used for da'wah equivalent word in English is mission, da'wah, or da'wah. Studies in the Christian religion, there is a branch of science called with missiology, the science spread the teachings of Christ. The mission said that is often used to describe efforts of proselytism.

Max Muller divides religion into two groups, using the term of missionary religion and non-missionary religion. He puts Buddhism, Christianity, and Islam into the missionary religion, whereas in non-missionary religion he adds Jews, Brahmins and Zoroastrians. ${ }^{3}$ Generally, these three

\footnotetext{
${ }^{3}$ See Thomas W. Arnold, The Preaching of Islam, 5.
} 
equivalents of the word are used in the literature which talks about the broadcasting of religious teachings. Of course the use of these three word equivalents is not always appropriate when applied for da'wah. It seems to consider that, McGill University uses the term of community development to refer Islamic Community Development studies program, which is abbreviated by PMI (Pengembangan Masyarakat Islam), a program in the Faculty of Da'wah and Communication Sciences Syarif Hidayatullah Jakarta in Social Welfare concentration.

In the context of da'wah Science, PMI is actually a translation of da'wah bil hal which is popularly understood in the sense of da'wah through action. While the term of da'wah bi al-bal-which is derived from the phrase proselytizing language da'wah bi lisan al-hal as an integral portion of the media/wasila da'wah, namely da'wah bi al-lisan (speaking) and da'wah bi al-kitabah (writing).

Muhammad Abu al-Fath al-Bayanuny defines da'wah by "conveying and teaching Islam to people and applying it to human life". "The Bayanuny's definition is very broad impressed object general human concerns. Therefore, Sheikh Ali Mahfudz gives little emphasis to the goal of happiness to be achieved. He defines it by saying encouraging people to do a good and to follow directions and to prevent evil deeds in order to gain happiness in the world and the hereafter. ${ }^{5}$ Bahi al-Khuly explains that the mission was "an attempt to move people from one situation to a better situation". ${ }^{6}$

${ }^{4}$ M. Abu al-Fath al-Bayanuny, al-Madkhal ila 'Im ad-Da'wah, (Beirut: Muassasah ar-Risalah, 1991), 17. 1975), 7.

${ }^{5}$ Syekh Ali Mahfudz, Hidayah al-Mursyidin, (Qahira: Dar al-Mishry,

${ }^{6}$ Al-Bahi al-Khuli, Tazkirat ad-Du'at, (Mesir: Dar al-Kitab al-'Arabi, 1952), 27; and see also M. Quraish Shihab, Membumikan Al-Qur'an, (Bandung: Mizan, 1992), 194. 
Thus da'wah as it is understood is an invitation or call to create a peaceful atmosphere and serene peace. It is an invitation to understand and implement the values of Islam in real life. There is a process of changing or moving the situation of people who do not give to the exciting situation, from the society that often brawl to the peace-loving people and carry out the peace with real. Therefore, da'wah essentially means building communication, which is done by someone with others to deliver a message. It is formulated by Harold D. Lasswell with the definition given, saying, "who says what in which channel to whom with what effect." There is an important note here which is about the influence of communication.

Coincide with the meaning of communication, da'wah also should have nuance impact. This termed atsar adda'wah (the former/the influence of da'wah), is another element that must be incorporated into arkan ad-da'wah. Thus, there will be mutual communication in the process of da'wah.

It is academically no doubt there is a process of social interaction in communication when the da'wah process starts running. There must be an effort to build meaning and consciousness which in the next turn will bear the pattern of thinking and the pattern of behaviour and the pattern of action in real action. This is where the necessary elements are intertwined with each other between message spreaders, media channels, the message itself, the recipient of messages, and the effects it produces.

In connection with efforts to stem the influence of secular life, the da'wah should be an inseparable part of the changes that occur due to the spread of messages of da'wah. Atsar ad-da'wah inevitably being part of the pillars of da'wah itself to ensure methodologically da'wah was able

${ }^{7}$ R. Anderson and V. Ross, Question of Communication: a Practical Introduction to Theory, (New York: Santa Martin's Press, 1998), 254. 
to give change. So change takes place in the mindset, thus building awareness within a person, ultimately building a behavioural pattern that will manifest in the daily deeds of a mad'u. Thus, it can be said that the secular life that separates religion in public life, or only becomes a private matter, will get interrupted from da'wah activities.

\section{Method}

This research is a field study supported with library research. The primary data is sourced from the activities of Al-Falah Mosque in Berlin which is da'wah and has been designed and implemented. Therefore, the focus of this research problem is da'wah activities conducted by Al-Falah Mosque IWKZ Berlin. From the exploration through the initial survey with the method of observation on author's previous visit, there are activities of da'wah in the form of recitations with mad' $u$ of various ages conducted by Al-Falah Mosque Berlin. Of course, these activities are a major source of data collection in this research.

This research is divided into three activities. Firstly, from May to July 2016, the initial activities include materials collection both theoretically and practically, problem identification, problem formulation, thereby obtaining an interview instruments for data collection. This activity was conducted in Indonesia, precisely in Ciputat, South Tangerang, which is on UIN Syarif Hidayatullah Jakarta campus. Secondly, from July to September 2016, is data collection from activity of da'wah Al-Falah IWKZ in Berlin. This was conducted in Germany. More specifically is done at the Al-Falah Mosque of Berlin. In July and August the activities focused on interviews and observations of da'wah activities of Al-Falah Mosque. To obtain more accurate data, the author conducted participant observation. This 
is possible because, at certain times author also asked to be the source in the da'wah activities. While in September the author use to compile initial report of research by doing interpretation of data obtained. Finally, from September to October 2016, is the final activity of this research, after returning to the homeland. The activities are re-reading of the initial interpretation of the data, which has been the author done in Berlin.

Extraction of information that the author does through the interview is a form of information that is closely related to the activities of da'wah Al-Falah IWKZ Mosque. This was done as a field assignment because the information was not found in the written sources owned by Al-Falah Mosque. Meanwhile, the written source on the various information that the author needs from online sources, taken by accessing these sources. In addition to interviews and reading of written sources, the author also conducts participatory observation. As for interviews, the author asked to six resource persons who hold the main position in various aspects of da'wah activities of Al-Falah Mosque, namely as follows:

a. Dipl-Ing, Dimas Abdirama, Vorstandsvorsitzender (Chairman of the Board of Prosperity Mosque), on $15^{\text {th }}$ August 2016;

b. Alif Zulfika, participants of Bina Iman and Takwa (MABIT) Ganteng-Ganteng Subuhan (GGS), on $11^{\text {th }}$ August 2016;

c. Wahyudi, Head of Al-Hisab Studies: The Fathers' Recitation, on $15^{\text {th }}$ August 2016;

d. Nury Maulida Raraswati, Chairman of Ummul Falah: The Mothers' Recitation, on $28^{\text {th }}$ August 2016; 
e. Dewi Yuniasih, member of Ummul Falah, on $28^{\text {th }}$ August 2016;

f. Zulkifli Indra Gading Nasution, initiator of MABIT / Ganteng-Ganteng Subuhan (GGS), on 29 ${ }^{\text {th }}$ August 2016.

This uses qualitative methods, with in-depth analysis of the phrases, statements, and information that can be extracted from the established resource persons. By using this method, it is hoped to be able to express deeply and comprehensively the da'wab activities conducted by Al-Falah Mosque of Berlin in an effort to stem the influence of secular life against Indonesian society which is Moslem in Berlin.

Middleton, as quoted by Atho Muzhar, explains that there is a kind of research in the form of research on religion and religious research. Research on religion emphasizes religious material, while religious research emphasizes religion as a system. ${ }^{8}$ Based on the theory of this research using mixed method approach (mixed methods) with a case study approach (case studies).

In other words, the focus of this research is the study of religious (religious research) or research on behaviour diversity displayed by the Indonesian Moslem community in Berlin. That is why the aim is how they view the activities undertaken by Al-Falah Mosque in stemming the influence of secular life. Finally, to interpret facts and data, the authors use the phenomenological method to read what is implied behind the facts and data. This method is very relevant to apply in order to fully disclose what is presented from the field so as to present true picture of the da'wah activity of Al-

${ }^{8}$ M. Atho Muzhar, Pendekatan Studi Islam dalam Teori dan Praktek, (Yogyakarta: Pustaka Pelajar, 2011), 35. 
Falah Mosque in Berlin to stem the influence of secularism on Indonesian society that is Moslem in Berlin.

\section{Discussion}

Starting from the understanding of the secular character of society, which also characterizes the Berlin community, that religion is merely a private matter of community members, not a public issues. Religious affairs-private personal affair and not a matter for a joint is moved through the mechanism of da'wah of al-amr bi al-ma'ruf wa an-naby 'an al-munkar (told to do a good way and prevent it from evil deeds). If the amar makruf and nabi munkar no longer run around Moslem community in the next turn that will happen the relaxation of religious spirit and the implementation of religious teachings on each individual self. Because no one warns anyone in the event of an act or behaviour that is inconsistent with religious teachings.

This situation is faced by the Moslem Indonesian in Berlin. There is no doubt that this situation requires a serious handling, so that the diverse Indonesian Moslem community in Berlin is not dragged into the circle of secularism. This effort needs to be done as a form of awareness as the implementation of da'wah amar makruf nabi munkar. It is true to say that without the presence of Al Falah IWKZ Mosque, the religious atmosphere of the Indonesian Moslem community living in Berlin will experience a decline in quality. As Dimas Abdirama, Vorstandsvorsitzender (Chairman of DKM) AlFalah Mosque said the presence of Al-Falah Mosque serves as an "Oasis" for Indonesian Moslems in Berlin."

That is why the issue of secular life becomes a serious issue among Indonesian Moslems. It can be proved that without the presence of the Al-Falah Mosque at any given

\footnotetext{
${ }^{9}$ Interview with Dipl-Ing Dimas Abdirama, on $15^{\text {th }}$ August 2016.
} 
time, it will create a culture of cultural alienation, which at the same time also becomes an alienation of religious mood. This is acknowledged by Dimas Abdirama, that one of the focus of the service of Al-Falah IWKZe.V Mosque is to create Islamic life for Indonesian Moslem community in Berlin which includes inculcating the subjects of Islamic teachings to be understood and practiced by the congregation. Al-Falah Mosque routinely conducts Islamic studies for various ages and classes, with which it is hoped that pilgrims can apply the glory of Islam in everyday life from including in order to protect themselves from various currents that contrary to Islamic teachings. ${ }^{10}$

Therefore, below will be presented a thorough analysis with phenomenological approach, related to da'wah activities conducted by Al-Falah IWKZ mosque in stemming the flow of various schools that are opposed to Islam. Of course, in particular the opposite view of Islam is the ideology of secularism faced by the Indonesian Moslem community in Berlin.

Monthly Pengajian activities designed by the Al-Falah Mosque once a month, giving a significant meaning for maintaining the intensity of the religious atmosphere in private life. Sociologically this activity is a silaturrabim event that gives a sense of togetherness among the people of Moslem Indonesian in Berlin. Social interaction that occurs in the occultation of the monthly study builds communication by exchanging information among one another.

In religious approach can be said that pengajian activities that contain religious tawsiyah provide added value for one's faith. It cannot be denied that the frequent person listening to the Qur'an will have an effect on improving his faith.

\footnotetext{
${ }^{10}$ Interview with Dipl-Ing Dimas Abdirama, on 15 ${ }^{\text {th }}$ August 2016.
} 
Especially when it is placed on the value of faith that can sometimes increase and also be reduced, as reported by the hadith of the Prophet Muhammad. That one's faith can grow and can be reduced "al-iman yazid wa yanqush" (that iman can grow and can be reduced). Thus the Monthly Pengajian, the faith of the study participants who follow it can grow or increase from the previous.

The study material that was put forward at that time was Q.S. al-Ahzab [33]: 34-35. As it is known that the verse affirms the 10 (ten) virtues of a Moslem and a Moslemat in life. The ten virtues are as follows: Islam, Iman, obedience, honesty, patience, religiousness in worship, charity, fasting, maintain of self-respect, and the fondness of ziker always remembers Allah.

It cannot be denied that the ten virtues or wealth presented in the recitation are closely related to efforts to increase religious understanding and strengthen one's identity of faith. In facing the effects of secularism. Imagine, the ten qualities of self-contain spiritual energy that can fortify a person from the temptations and disturbances that arise in life. If the tenth qualities of self-described in the study can be practiced, it will be able to stem the influence of secularism. Using ten qualities of the self-awareness someone will be awakened faithful members of the recitation memorable memorize each other in everyday life.

Pengajian Umm Al-Falah, in this case talking about Shia and Ahmadiyah. The theme of Shia and Ahmadiyah is the theme demanded by Ummul Falah's own study. Here, the motivation to talk about what Shia and Ahmadiyah is a sign of the curiosity of the teaching recitation members that appear in Islam as a splinter flows opposite the Ablussunnah wal Jama'ah grip. As is known to the Shia, it is a doctrine which emphasizes the views on the priesthood of Ali ibn Abi Thalib, 
and rejects all the traditions narrated by the companions of the Prophet who did not accept the priesthood of Ali ibn Abi Thalib. This has far-reaching consequences, that almost all forms of worship considered legal syar'i in the view of Ahlu Sunnah wal Jamaah are dispersed. Of course the Shia presentation in such an understanding becomes part of an effort to raise religious awareness among Ummul Falah recitation members themselves. In the next turn this increase in religious awareness becomes a concrete form of efforts to stem the effects of secularism in life, both individual life, and social life. It can be ascertained by the understanding of Shia religious ideals, the common consciousness of which the Ablussunnah wal Jama'ah believed, held by the majority of the ummah can be known without any doubt upon it. Thus efforts to stem understanding and secular behaviour can be done.

Similarly, talks on Ahmadiyah, especially the Qadiniyah, believes that Mirza Ghulam Ahmad is the Prophet after the Prophet Muhammad saw. Mirza Ghulam Ahmad even admitted that he received a revelation from God, which he later named by Tazkirah. In view of Ahmadiyah Qadianiyah, Tazkirah this is an indispensable part of the Qur'an.

It is true that Ahmadiyah say the Prophet Muhammad saw. Is the last prophet as understood by Ablussunnah wal Jama'ah, while Ahmadiyah said that the Prophet Muhammad saw is the last Prophet who brought sharia. Allah still send prophets after the Prophet Muhammad which does not bring sharia. From this simple explanation it can be seen that the curiosity of the members of the Qur'an and the Ahmadiyya teachings indicates a passion for improving and straightening understanding of Islam. That Islam is understood must be in accordance with the basis of the Qur'an and authentic Hadith. Deviation from the Qur'an and authentic Hadith 
is a form of unlawful religious practice and it is a form of real error.

The above is a form of cognitive understanding of religion. Represented by the question of how the law when praying with an Ahmadiyah priest is a manifestation of motor consciousness in the implementation of religious teachings in a ritual. Questions arise about shalat congregation, but the imam is an Ahmadiyah, is this prayer valid, as presented above, becoming an evidence of concern of pengajian members to their religion. The question certainly arises from the religious practice that has been implemented and wants a clarification of the prayers that pilgrims do. With the emergence of these questions indicate that there is still concern for the implementation of religious rituals that can be accepted syar'i.

Similarly, the same thing arises in the question of the implementation of the Tarawih prayer at the home of a non-Moslem, because a rather large place exists only in that area. Is the Tarawih prayer justified? Certainly this question arises as evidence of the participants towards religious teachings that should not deviate from the provisions of syar' $i$. This is acknowledged by Dewi Yuniasih, one of the members of pengajian Ummul Falah. According to Dewi Yuniasih, in my opinion, Ummul Falah's study influence on religious consciousness is significant. He further explained that usually, mothers who regularly attend in their pengajian more aware to maintain their Islamic amid a secular Berlin society, such as sunnah prayers in addition to obligatory prayers, and also the fasting of circumcision in addition to Ramadan fasting. Awareness to maintain and become a mosque donor is also quite high. ${ }^{11}$

\footnotetext{
${ }^{11}$ Interview with Dewi Yuniasih, on $7^{\text {th }}$ September 2016.
} 
It is clear that Dewi Yuniasih's explanation above can be used as an indication, how the da'wah activities conducted by Al-Falah Mosque Berlin has a significant meaning for efforts to stem the influence of secular life faced by the people of Indonesia who are Moslems in Berlin. It is also felt by Nurry Maulida Raraswati, who says that the influence can be seen from how Umm al Falah's formerly un-hijacked women began to be veiled, cautious in the things that are haram and halal (especially food and drink), diligently reading al-Ma'tsurat early in the afternoon, reciting al-Kahf Surah every Friday, also reciting al-Mulk Surah before going to bed. In addition to growing the movement invites other mothers to come to the mosque as well as to study the Qur'an. Mothers who were not able to read Qur'an so can read Qur'an, although began to study at age $40^{\mathrm{s}}$ and even there is a new noble age 50 s. Growing gifts of charity for the mosque (especially in Ramadan), enliven/prosper the mosque, and others. ${ }^{12}$

As well as al-Hisab, recitals devoted to the father is more nuanced mujadalah or dialogical in two-way communication, instead of mau'izah or teaching in a one-way communication. Sometimes the debate is quite serious, but within the bounds of "even though the hot heart, keeps the head cold." The cross of argumentation is quite sharp, but it is limited to the time of the discussion. It may be different, but should not be divisive. This is the spirit which is always alive in the pengajian al-Hisab. It is not necessary to argue that what is presented in the recitation material used as material in this research, the interpretation of Ayat Kursi in the Qur'an, becomes an indication of awareness of the Qur'an. This is a motivation for the study of al-Hisab.

This can be understood from the explanation given by Wahyudi, the leader of al-Hisab. "In addition to improving

\footnotetext{
${ }^{12}$ Interview with Nurry Maulida Raraswati, on $28^{\text {th }}$ August 2016.
} 
the religious understanding of the worshipers and their families, this recitation is also to improve the Qur'an reading of the pilgrims whose level of Qur'anic reading ability is still very low". ${ }^{13}$ Indeed, the author observed that it is known ability to read Qur'an recitation of the pilgrims is very diverse. From a very minimal to ability tartil Al-Qur'an well. With an increasing understanding of Islam and applied directly to the daily lives of Moslem communities, in addition of interaction/friendship among the, who continue to be fostered, at least Islamic values is still awake in the life of the congregation in a secular country like in Germany. So the influence of this recitation is quite large in stemming secularism, because when dealing with state secular law only is used by Moslem communities, while in daily life Islamic values is still firmly attached.

In the future, the study of al-Hisab will be developed by seeking counsellors/materialists who master a wide range of religious knowledge to compensate for the life experiences of senior Moslem communities comprised. During this time the material speaker is only taken from the people who are considered more understanding than others. Furthermore, in every recitation always inserted a discourse that motivates the father to continuous improvement of worship. Innovation of themes and programs to keep the spirit of recitation, such as open nature recitation (natural tadabbur) while recreation and inter-city recitation (visiting Indonesian Moslem communities in other cities). ${ }^{14}$

As a weekly periodic activities, the Friday prayers at Friday Khotbah in it being part and parcel of the effort to maintain the intensity of the faith of every Moslem. This weekly periodic meeting gives its own strength to the Moslem

\footnotetext{
${ }^{13}$ Interview with Wahyudi, on $15^{\text {th }}$ August 2016.

${ }^{14}$ Interview with Wahyudi, on $15^{\text {th }}$ August 2016.
} 
community with the opening of social interaction space In the authentic hadith it is explained that leaving the Friday prayer three times in a row, it will be locked in its heart. In a different hadith also mentions that leaving three Friday prayers, he has thrown out Islam. In the Qur'an itself, Friday prayer explained that every Moslem is obliged to perform the Friday prayers, even he must leave the sale for the upright prayer Friday. The statement regarding the obligation of Friday prayer is described in Q.S. al-Jumu'ah [62]: 9:

O you who have believed, when [the adhan] is called for the prayer on the day of Jumu'ah [Friday], then proceed to the remembrance of Allah and leave trade. That is better for you, if you only knew. (Q.S. al-Jumu'ah [62]: 9)

Obligations Friday prayers are also described in a variety of authentic hadith, among others, the following hadith:

Friday prayer is obligatory for every Moslem in congregation, except four (groups) i.e. bondsmen, women, children and the sick. (H.R. Sunan Abu Dawud)

The obligation of Friday prayer congregation in essence waking Moslem community social interaction in the system of worship that have a social dimension. Ideally, conceptual, surely the Friday prayers and listen to sermons Friday is intensity preservation and maintenance of the faith nuance. Among of the people in Berlin who secular, the existence at the mosque listened Friday Khotbah clearly has a special meaning for those with a certain level of seriousness attend.

Moreover, when related to the theme of Khoutbah that made the object of study in this research, the Joy of Living in the Lower Shade of the Qur'an. This theme is very relevant to establish an attitude in life in order to stem the secular life. With the shelter under the Qur'an, in the sense of duties life in accordance to the guidance of the Qur'an, in fact, no 
one is making religion as a private matter. Further explained by the preacher that way under the auspices of Qur'an, it is to perform the following seven steps:

a. Qur'an is the main textbook;

b. Qur'an as the first reading and most noble;

c. Qur'an as the main reference in the formation of thought, intellect, and character;

d. Qur'an as the spirit of life (الرُّوحُ);

e. Qur'an as the light of life (النُّوحر));

f. Qur'an as living directive (the way of life) (الْهُدَى);

g. Qur'an as warning (تَذْكرَةًر).

As a generation of hope, youth is a strategic objective in proselytizing activities of Al-Falah Mosque. As mentioned in the data activity findings undertaken to work on this segment is Malam Bimbingan Iman dan Takwa (MABIT), later on changed becoming Ganteng-Ganteng Sububan (GGS). Interestingly, this event is initiative and its implementing originated from the youth themselves. Zulkifli Gading Indra Nasution, the initiator of this event explained that the speaker is coming from the youth themselves. In addition to the speaker there is a moderator. We want to train the youth to dare to speak in public on a small scale. It is expected that youth dare to speak in public in a larger scale in the future. The material presented is not specified as long as it is not divisive. ${ }^{15}$

Maintaining the religious atmosphere among youths in the city with a secular society is certainly a strategic effort for the development of Islam. At the same time, it is also an effort that is not easy to do. But with triggering youth themselves as committee, already proved that it has not small effect of guard religious awareness among the youth.

${ }^{15}$ Interview with Zulkifli Indra Gading Nasution, on 29 ${ }^{\text {th }}$ August 2016. 
Although it is only lasted a month, in the holy month of Ramadan, Ramadan Activities pursued by the mosque is to be especially effective in maintaining the intensity of faith in the secular society like in Berlin. It is true that impression needs to be confirmed by the statements and confessions felt by the Indonesian Moslem community in Berlin.

This is revealed in a vision, which states that being a Moslem Indonesia in Berlin, Germany, has a blessing. At least it says Fairuz, one Indonesian citizen who has been living in Berlin. Further, he said that "Our position as a minority would bring good luck. As the month of Ramadan, for example. Here we can fasting with more focus reproduce worship. Unlike when in Indonesia. It is nice to be back home, but during Ramadan time instead discharged to the invitation of fasting. The impact iftar are often held at the mall, we often end up even through the afternoon prayer on Eid. Here, there is no event like it. If anything, the holding must have here, in the al-Falah mosque."16

Fasting in Berlin in the summer has external and internal challenges. The internal challenge is a very long time, between 19 and 20 hours a day. It is not like as fast in the homeland. While the challenges from outside the community atmosphere of Berlin in the summer, the clothes they are all minimal and barely even open. An atmosphere like that every day they meet in the month of Ramadan in the summer season. Therefore, the advice to always carry the Qur'an wherever you go is very meaningful and helpful intensity of one's consciousness in maintaining the sanctity of fasting that is being done. By constantly reading the Qur'an, mood will always be maintained and preserved as well as being in the shadow of the Almighty.

${ }^{16} \mathrm{http}$ // / muslimtraveling.com/kompaknya-muslim-indonesia-di-berlin, accessed on $21^{\text {st }}$ July 2016. 
From the overall interpretation, it is true what is said by Dimas Abdirama found that a focus on services Al-Falah IWKZe.V Mosque is to create an Islamic life for Indonesian Moslem community in Berlin that included implanting the principal teachings of Islam in order to be understood and practiced by the congregation. Al-Falah Islamic Mosque studies routinely held for all ages and groups, with which the pilgrims are expected to apply the glory of Islam in daily life from including in order to protect themselves from various currents opposed to the teachings of Islam. ${ }^{17}$

Among the current doctrine contrary to the teachings of Islam that is the understanding of secularism. Secular life faced by the Indonesian Moslem community in Berlin somewhat affect religion awareness that they have. Religion was previously believed in the country, when it enters the life of Berlin, a little more degraded. As revealed, this quality degradation condition will lead to a reduction in the level of consciousness over time.

\section{Conclusion}

From exposure to information about Berlin secular society, which gives effect to the Indonesian Moslem community in Berlin, as well as the presence of the AlFalah Mosque Indonesisches Weisheitits-und Kulturzentrum IWKZe.V Berlin with various da'wah activity does, it can be deduced as follows:

1. The da'wah activities carried out by the Al-Falah Mosque Indonesisches Weisheitits-und Kulturzentrum (IWKZ) Berlin to stem the influence of secular life faced by Indonesian Moslem community in the city of Berlin;

\footnotetext{
${ }^{17}$ Interview with Dipl-Ing Dimas Abdirama, on 15 ${ }^{\text {th }}$ August 2016.
} 
2. The da'wah activities carried out by the Masjid Al-Falah Indonesisches Weisheitits-und Kulturzentrum (IWKZ) Berlin They come in a variety of da'wah by considering the age group, gender and availability of time required for each activity;

3. Various forms of da'wah that is Monthly Pengajian, Umm Al-Falah (The Mother recitation), Al-Hisab (The Father recitation), Malam Pembinaan Iman dan Taqwa (MABIT), Friday Khotbah, and Ramadan activities;

4. As the findings of a side, there are the problems faced by the Indonesian Moslem community in Berlin that need attention. The problem is the diversity of Indonesian children who were born in Berlin which is very susceptible affected secularism. 


\section{REFERENCES}

al-Bayanuny, M. Abu al-Fath. al-Madkhal ila 'Ilm ad-Da'wah.

Beirut: Mu'assasah ar-Risalah, 1991.

al-Khuli, al-Bahy. Tadzkirat ad-Du'at. Mesir: Dar al-Kitab al'Arabi, 1952.

Anderson, R and V. Ross. Question of Communication: a Practical Introduction to Theory. New York: Santa Martin's Press, 1998.

Mahfudz, Syekh Ali. Hidayah al-Mursyidin. Qahira: Dar alMishry, 1975.

Muzhar, M. Atho. Pendekatan Studi Islam dalam Teori dan Praktek. Yogyakarta: Pustaka Pelajar, 2011.

Rachman, Budhy Munawar. Reorientasi Pembaharuan Islam Sekularisme Liberalisme: Paradigma Baru Islam Indonesia. Jakarta: Lembaga Studi Agama dan Filsafat, 2010.

Shihab, M. Quraish. Membumikan Al-Qur'an. Bandung: Mizan, 1992.

\section{Interviews:}

Interview with Dipl-Ing, Dimas Abdirama, Vorstandsvorsitzender (Chairman of the Board of Prosperity Mosque), on $15^{\text {th }}$ August 2016.

Interview with Alif Zulfika, participants of Bina Iman and Takwa (MABIT) Ganteng-Ganteng Subuhan (GGS), on $11^{\text {th }}$ August 2016.

Interview with Wahyudi, Head of Al-Hisab Studies: The Fathers' Recitation, on $15^{\text {th }}$ August 2016. 
Interview with Nury Maulida Raraswati, Chairman of Ummul Falah: The Mothers' Recitation, on $28^{\text {th }}$ August 2016. Interview with Dewi Yuniasih, member of Ummul Falah, on $28^{\text {th }}$ August 2016.

Interview with Zulkifli Indra Gading Nasution, initiator of MABIT/Ganteng-Ganteng Subuhan (GGS), on 29 $9^{\text {th }}$ August 2016. 
